\title{
Students' Characteristics as Indicator for Effective Teaching
}

\author{
Aziz Nordin ${ }^{\mathrm{a}^{*}}$ \\ aUniversiti Teknologi Malaysia, 81310 UTM Johor Bahru, Johor, Malaysia \\ *Corresponding author: p-aziz@utm.my
}

\section{Article history}

Received :11 December 2012

Received in revised form:

30 August 2013

Accepted : 15 September 2013

\begin{abstract}
Students are the most valuable asset to a country. The success of students in learning science and mathematics not only depends on how well the educators look into the students' needs per se but also and the interactions of both parties during teaching and learning processes. Therefore, this research was carried out to gather information and to formulate the standard criteria for teaching and learning science and mathematics. The research instruments were the set of questionnaires that were designed to identify students' abilities, background, perception, students' interests and motivation, multiple intelligents, thinking styles, learning style and creativity on teaching and learning science and mathematics. The respondent consists of 101 second year and 104 third year students who have taken science and mathematics programs. The research found out that there are interesting patterns of students' performance according to their characteristics. Finally, the findings revealed that there are challenges for the science and mathematics educator to make use students' characteristics to promote optimum learning among students.
\end{abstract}

Keyword: Teaching science and mathematics

\begin{abstract}
Abstrak
Pelajar merupakan aset paling berharga kepada sesebuah negara. Kejayaan dalam pembelajaran sains dan matematik tidak hanya bergantung pada bagaimana pendidik meneliti keperluan pelajar tetapi juga mengenai hubungan antara kedua-dua pihak semasa proses pengajaran dan pembelajaran. Oleh itu, kajian ini dijalankan untuk mengumpul maklumat dan untuk merangka kriteria standard bagi pengajaran dan pembelajaran sains dan matematik. Instrumen kajian ialah set soal selidik yang direkabentuk untuk mengenal pasti keupayaan pelajar, persepsi latar belakang, minat dan motivasi pelajar, kecerdasan pelbagai, gaya berfikir, gaya pembelajaran dan kreativiti pengajaran dan pembelajaran sains dan matematik. Responden terdiri daripada 101 pelajar tahun 1 dan 104 pelajar tahun 3 yang mengikuti program sains dan matematik. Kajian ini mendapati terdapat corak yang menarik mengenai kemajuan pelajar mengikut ciriciri mereka. Akhirnya, hasil kajian mendedahkan bahawa terdapat cabaran bagi pendidik sains dan matematik untuk memanfaatkan ciri-ciri pelajar untuk menggalakkan pembelajaran yang optimum dikalangan mereka.
\end{abstract}

Kata kunci: Pengajaran sains dan matematik

\subsection{INTRODUCTION}

As a nation that is progressing towards a developed nation status, Malaysia needs to create a society that is scientifically oriented, progressive, knowledgeable, having a high capacity for change, forward looking and innovative to contribut in scientific and technological developments (Curriculum Development Centre, 2006).

Human resource is the most crucial asset to a country. Education plays an important role in establishing human resources with noble characters, high levels of knowledge and skills to fulfil the requirements of a developed country in the year of 2020 (Kementerian Pelajaran Malaysia, 2006). The National Philosophy of Education states that education in Malaysia is an on-going effort towards developing the potential of individuals in a holistic and integrated manner; intellectually, spiritually, emotionally and physically balanced and harmonious based on a firm belief in and devotion to God. In consonance with the National Education Philosophy, science education in Malaysia nurtures a science and technology culture by focusing on the development of individuals who are competitive, dynamic, robust and resilient and able to master scientific knowledge and technological competency (Curriculum Development Centre, 2006).

Students learn best when there is congruence between their preferred learning styles and the teacher's preferred teaching style. Students' styles should, therefore, influence teachers' instructional choices (Tan et al., 2003). Unfortunately and all too often, teachers ignore learning style variations and teach all students the same way. The traditional teacher-centred talk and chalk pedagogy practised by most teachers in Malaysia will not benefit students with varied 
learning styles. Only a small percentage of secondary students were capable of listening to a lecture on new and difficult academic material in between 40-50 minutes and of remembering at least $75 \%$ of what they heard (Honigsfeld \& Dunn, 2003).

Being sensitive to the diversity of the students and being aware of the research on student differences can assist teacher to develop teaching-learning activities tailored to their students' unique strengths and limitations (Tan et al., 2003). For instance, when teachers are aware of the differences in modality preferences of their students, they would choose a variety of teaching and learning activities that address the differences. If students are going to learn the particulate nature of matter, the teachers could design lessons with a combination of oral explanations (appeal to auditory learners), computer simulations (appeal to visual learners), diagram drawings (appeal to tactual learners), and laboratory activities to investigate the diffusion of particles (appeal to kinaesthetic learners). Taking into consideration the strengths and limitations of students when choosing strategies and activities for chemistry lessons proved that students will enjoy the lessons more and learn more effectively, obtaining better achievements.

Several studies showed that science subject was one of the interesting subjects but it was a difficult one to learn (Aziz, 1990 and 1992). Students frequently encounter science problems involving calculations, understanding of concepts and chemical reactions. Similarly, in learning mathematics, students are also frequently encountered mathematics problems involving calculations, understanding of concepts, principles and mathematical relationship with others subjects. Students perceive both subjects were important and interesting subjects even though both subjects are also very difficult to learn (Aziz, 1992). The reasons are due to the facts that the concepts in science and mathematics are abstract and difficult to comprehend - the students have alternative meaning of certain science and mathematical words before any science and mathematics teaching takes place (Aziz, 2003). However, according to Ihejieto (1995), there are nonacademic factors which could explain the performance trend, such as students' dislike for mathematics that may stem from psychological incidences, the mathematics curriculum may have not much relevance to real life situation, mathematics teachers were not interested in the subject and did not help their students by way of catering for individual differences and other resources material such as text books seemed lacking in both in school and at home.

Teaching and learning strategies, pedagogy, teaching resources and technology are aspects that need to be highly considered by educators. The correct choice among those aspects will contribute to the effectiveness of teaching and learning process. When planning lessons for the students, educators should take into consideration many aspects. These include the aims of education, curriculum, characteristics of students and pedagogy. Among the characteristics of students are their interests, abilities, background, multiple intelligents, thinking styles, creativity and learning styles. An ideal teaching and learning process would be one that is able to match the aims of education and the curriculum with students' characteristics. In such an ideal situation, educators would teach effeciently while students learn effectively.

However, from the experiences of many educators, the atmosphere in learning institutions does not reflect the ideal situation as dreamt. Most of the students did not pay full attention to the teaching process. Instead, they often talk to one another, scribble all over their books, dreaming or even do other jobs that interest them. Do students with certain characteristics or traits enjoy and benefit more from the teaching strategies applied by most of the educators? What are the formulation that could help students and educators toward science and mathematics teaching and learning process?

\subsection{STATEMENT OF THE PROBLEM}

Based on the observations of many educators, not many sciencestream students enjoy studying in school and perform well in Science subject. The analysis of the results of internal examinations in higher institutions always reveal that only a small portion of candidates obtain excellent scores in Science and Engineering subject although the passing percentages marks are high. It has become a norm that the number of students getting low grades is greater than those getting excellent grades. Research has shown that on average, good learning instructions increased the achievements or improved the attitudes toward learning, or both, of all students (Lovelace, 2005). A study should be carried out to identify students' traits toward science and mathematics teaching and learning process. With that, the needs of students with certain characteristics or traits that have been neglected would be identified. The findings of the study could also be used as a reference for educators when they plan their lessons so that the teaching and learning process would benefit all the students.

\subsection{PURPOSE OF THE STUDY}

The objectives of the study are as follows:

- To identify the students' abilities, backgrounds, interests, multiple intelligents, thinking styles, learning styles and creativity among the science and mathematics students.

- To identify the patterns of students' abilities, backgrounds, interests, multiple intelligents, thinking styles, learning styles and creativity among the science and mathematics students according to their performances.

\subsection{RESEARCH METHODOLOGY}

A survey was conducted at Universiti Teknologi Malaysia. The data for the research were collected from two groups of students, a second and third year course taking science and mathematics subjects. A total of 205 respondents participated in the research. The respondents were randomly selected. Questionnaires were used to obtain data for each characteristic as the instruments for data collection. The instrument consists of multiple intelligent which was developed by Gardner (1983), motivation questionnaire from Spielberger et al. (1970), thinking style inventory (Sternberg and Wagner, 1992), learning style by Honey and Mumford (1992) and Torrance and Guilford questionnaire (Torrance 1974; 1988; Rafedah, 2009 and Nurul Hamizah, 2010) for creativity. The responses given by the respondents were collected and later analysed using SPSS (Statistical Package for Social Science for MS Windows Release 10.0) software. The statistical analyses used in the research were frequencies and percentages. The analysis of the results of the research is shown in Tables 1 to 16 .

\subsection{RESULT OF THE STUDY}

This paper discusses the students' traits that are necessary for educators to consider in teaching and learning processes. Students' traits analysed are as follows;

\subsection{Students' Background And Ability}

Research revealed that there are three main groups for UTM candidates. These students are from the Foundation program in 
UTM, Malaysian High School Examination (STPM), and Matriculation. The approximate percentage of students' yearly intake is shown in Table 1. Majority of the students are from Matriculation College followed by STPM and Foundation program.

Table 1 Percentage of second and third year students' entrance according to programmes

\begin{tabular}{lcc}
\hline \multicolumn{1}{c}{ Enrolment } & Second Year & Third Year \\
\hline Foundation program & 18.6 & 17.0 \\
Matriculation & 60.8 & 64.0 \\
STPM & 20.6 & 18.0 \\
Diploma Certificate & 0.0 & 1.0 \\
\hline
\end{tabular}

It is also found that majority of the third year students have good Science, Mathematics and English Language shown in their SPM results (Table 2).

Table 2 Percentage of SPM grade result of third year students according to the subjects

\begin{tabular}{cccccc}
\hline Grade & Chemistry & Physic & Mathematics & $\begin{array}{l}\text { Additional } \\
\text { Mathematics }\end{array}$ & English \\
\hline A & 51 & 31 & 97 & 55 & 51 \\
B & 43 & 51 & 3 & 34 & 38 \\
C & 5 & 16 & & 10 & 9 \\
D & 1 & 2 & & 1 & 2 \\
\hline
\end{tabular}

Moreover, it is also revealed that the students' achievements from different enrolment groups in UTM seem to show mark relationship to their previous achievement results (Table 3). Correlation analysis showed that UTM Foundation Program has high correlation value between their CGPA performances during pre-university program with their CGPA degree program in UTM, followed by STPM and Matriculation students respectively. This finding indicates that the pattern of students' performances during their pre-university in UTM is mostly maintained till their degree program. It seems that the students are familiar with the UTM way of life or culture. Unfortunately this may not indicate a good trend since low achiever students most likely will remain at their low performance levels. With the correlation value as low as $r=0.27$ it is very difficult to predict the result of Matriculation students at the end of their course in UTM. This correlation analysis indicates that for the purpose of the students' enrolment selection, good results from the Matriculation may not reflect a good result of CGPA achievement in UTM or vice versa.

Table 3 Correlation between CGPA of second year students in UTM with their CGPA before joining UTM

\begin{tabular}{cccc}
\hline & \multicolumn{3}{c}{ CGPA before joining UTM } \\
& $\begin{array}{c}\text { Foundation } \\
\text { Program }\end{array}$ & STPM & Matriculation \\
\hline CGPA in UTM & $0.747 *$ & $0.461 * *$ & $0.270^{* *}$ \\
\hline Note: & $*$ indicates significant level (p) at 0.01 & \\
& $* *$ indicates significant level (p) at 0.05 &
\end{tabular}

\subsection{Students' Interest and Motivation}

Motivation is a psychological characteristic that drives a human being into action. It paves the way for the attainment of a goal, without motivation everyone cannot achieve his or her goals. In fact, life could be very dull and less meaningful without it.
Motivation can be divided into two types: extrinsic and intrinsic. Intrinsic motivation refers to motivation that is driven by an interest or enjoyment in the task itself, and exists within the individual rather than relying on any external pressure. It is based on taking pleasure in an activity rather than working towards an external reward. While extrinsic motivation refers to the performance of an activity in order to attain an outcome, it is contradicted to intrinsic motivation.

In this study, interest is referring to individual or student interest. Student's interest has been described as a relatively enduring predisposition to attend to certain objects and events and to engage in certain activities. This behaviour is associated with a psychological state of positive affect and persistence, and tends to result in increased learning (Ainley et al., 2002).

Student's interest in a subject is considered to be a valuable motivational resource. Although it is acknowledged that some students entered the classrooms with strong pre-existing direct interests in the assigned subject matter, it is also assumed that other students will depend upon teacher mediation to formulate indirect interests in the content. It is found that teachers affect student's subject interest through: (a) curricular choices, (b) instructional strategies, and (c) levels of teacher's interest in the subject and the students. The level of one's interest has repeatedly been found to be a powerful influence on learning. Specifically, interest has been found to influence students' attention, goals, recognition, and recall; persistence and effort; academic motivation and their levels of learning (Slavin, 2006).

Table 4 shows that majority of the second year students have high extrinsic and intrinsic motivation. This means that the students are highly self motivated and interested in their study. With regards to this matter the educator needs to be more creative in planning a meaningful learning environment to promote and maintain students' interest in learning.

Table 4 Percentage distribution of extrinsic and intrinsic motivation level among second year students

\begin{tabular}{lcc}
\hline Motivation Level & Extrinsic (\%) & Intrinsic (\%) \\
\hline $1.00-2.50$ (Low) & 0 & 0 \\
$2.51-3.50$ (Medium) & 32.7 & 24.5 \\
$3.51-5.00$ (High) & 67.3 & 75.5 \\
\hline
\end{tabular}

For the motivation levels of students from different intakes, it is found that all the three students' groups have high mean of intrinsic and extrinsic levels (Table 5).The mean of intrinsic motivation score for the Foundation Program students is the highest (3.89) followed by STPM and Matriculation students. However, in the extrinsic motivation the highest mean score is the matriculation students and respectively followed by the foundation program and the STPM students.

Table 5 The mean of extrinsic and intrinsic motivation level among second year students

\begin{tabular}{lrc}
\hline Enrolment to UTM & Extrinsic & Intrinsic \\
\hline STPM & 3.52 & 3.79 \\
Matriculation & 3.75 & 3.78 \\
Foundation Program & 3.67 & 3.89 \\
\hline
\end{tabular}

\subsection{Students' Multiple Intelligence}

Gardner (1999) defines multiple intelligent as bio-psychological potential to process information that can be activated in a cultural setting to solve problems or create products that are of value in a 
culture. Multiple intelligent refers as the differing ways in which humans think and learn. The instrument used in this study was the Gardner Multiple Intelligent Test questionnaire (1983). The result is shown in the Table 6 and 7 below.

Table 6 shows that the highest multiple intelligent domain for third year students is intrapersonal $(27.7 \%)$ and followed by other intelligent domains. The distribution of multiple intelligent domains according to CGPA is shown in Table 7. The results show that there is unclear correlation pattern of multiple intelligent exist with CGPA level of the students.

Table 6 Distribution of multiple intelligent among third year students

\begin{tabular}{lcc}
\hline Multiple Intelligent Domain & Frequency & Percentage \\
\hline Intrapersonal & 28 & 27.7 \\
Logical-mathematical & 23 & 22.8 \\
Interpersonal & 22 & 21.8 \\
Verbal-linguistic & 12 & 11.9 \\
Bodily-Kinesthetic & 7 & 6.9 \\
Visual-spacial & 5 & 5.0 \\
Music & 4 & 4.0 \\
\hline
\end{tabular}

Table 7 Distribution of multiple intelligent among third year students

\begin{tabular}{lrccc}
\hline \multicolumn{1}{c}{ Multiple } & & CGPA & \\
\multicolumn{1}{c}{ Intelligent } & $\mathbf{2 . 0 0}$ & $-\mathbf{3 . 0 0}-$ & $\mathbf{3 . 5 0}-$ & Total \\
Domain & $\mathbf{2 . 9 9}$ & $\mathbf{3 . 4 9}$ & $\mathbf{4 . 0 0}$ & \\
\hline Intrapersonal & 4 & 13 & 11 & 28 \\
Logical-mathematical & 1 & 11 & 11 & 23 \\
Interpersonal & 2 & 8 & 12 & 22 \\
Verbal-linguistic & 1 & 4 & 7 & 12 \\
Bodily-Kinesthetic & 2 & 1 & 4 & 7 \\
Visual-spacial & 1 & 1 & 3 & 5 \\
Musical & 1 & 1 & 2 & 4 \\
Total & 12 & 39 & 50 & 101 \\
\hline
\end{tabular}

The result of the multiple intelligent analysis revealed that the third year students are comprised of different multiple intelligent domains and there is no clear correlation exists between performance with multiple intelligent domain.

\subsection{Students' Thinking Styles}

Thinking style describes the preferred thinking approach learners' use such as being inquisitive, analytical, visual, spatial or problem solvers. In this research modified Malay Language Sternberg instrument version was used to identify students thinking style and categorized according to mean standard developed by Sternberg (Vivian, 2007). Each individual learner may have more than one dominant thinking styles.

There were 97 students participated in this study and the highest number of intake is 59 students from matriculation followed by STPM (20 students) and 8 students from UTM foundation program (Table 8). The distribution pattern for second year intake is similar to the third year students (Table 1).

Table 8 Percentage of second year students according the program intake

\begin{tabular}{lcc}
\hline Enrolment & Frequency & Percentage \\
\hline Foundation Program & 18 & 18.6 \\
Matriculation & 59 & 60.8 \\
STPM & 20 & 20.6 \\
\hline
\end{tabular}

Table 9 shows that majority $(61.9 \%)$ of the second year students are grouped as good achiever (CGPA with 3.00 to 3.49), $28.9 \%$ students are excellent and $9.2 \%$ are medium achiever.
Moreover, research's findings as shown by Table 10, revealed that a student may possess more than one dominant thinking style. In excellent group students, monarchic (working on one task at a time), local (focusing on details) and conservative (using traditional approaches to tasks) are the top three preferred thinking styles. The preference looks similar for the good achiever students except with low respondents' percentages. Nonetheless, for the medium group students, they preferred working on multiple tasks with no priority (oligarchic) followed by monarchic, external and executive thinking style. From this observation, it can be concluded that all three groups of students have different thinking styles and different ways of solving problems. It was also found that there is low students' percentage who tend to be more creativity-generating and that denote higher levels of cognitive complexity, including the legislative (being creative), judicial (evaluative of other people or products), hierarchical (prioritizing one's tasks), global (focusing on the whole picture), and liberal (taking a new approach to tasks) styles (Zhang \& Sternberg, 2005).

Table 9 Percentage of second year students according to the CGPA

\begin{tabular}{ccc}
\hline CGPA & Frequency & Percentage \\
\hline $3.50-4.00$ & 28 & 28.9 \\
$3.00-3.49$ & 60 & 61.9 \\
$2.50-2.99$ & 9 & 9.2 \\
$>2.49$ & - & - \\
\hline
\end{tabular}

Table 10 Percentage of Students' Dominant Thinking Style according to CGPA

\begin{tabular}{lccc}
\hline Thinking Style & $\begin{array}{c}\text { Medium } \\
(\mathbf{2 . 5 0}-\mathbf{2 . 9 9 )}\end{array}$ & $\begin{array}{c}\text { CGPA } \\
\text { Good } \\
\mathbf{( 3 . 0 0 - 3 . 4 9 )}\end{array}$ & $\begin{array}{c}\text { Excellent } \\
\mathbf{( 3 . 5 0 - 4 . 0 0 )}\end{array}$ \\
\hline Legislative & 22.2 & 28.3 & 39.3 \\
Executive & 77.7 & 80.0 & 82.1 \\
Judicial & 66.7 & 58.3 & 71.4 \\
Monarchic & 77.7 & 86.7 & 92.9 \\
Hierarchic & 44.4 & 30.0 & 28.6 \\
Oligarchic & 100.0 & 86.7 & 78.6 \\
Anarchic & 66.7 & 50.0 & 60.7 \\
Local & 55.6 & 86.7 & 92.9 \\
Global & 66.7 & 38.3 & 64.3 \\
Internal & 11.1 & 66.7 & 64.3 \\
External & 77.7 & 41.7 & 53.6 \\
Liberal & 22.2 & 11.7 & 17.9 \\
Conservative & 66.7 & 86.7 & 89.3 \\
\hline
\end{tabular}

\subsection{Students' Learning Styles}

Students have different strengths and preferences in the ways they take in and process information-they have different learning styles (Felder \& Spurlin, 2005). Learning styles are different approaches or ways of learning. A learning style can be defined as a consistent preference over time and subject matter for perceiving, thinking about, and organizing information in a particular way (Sternberg \& Grigorenko, 2001). Keefe (1979) defines learning styles as the composite of characteristic cognitive, affective, and physiological factors that serves as relatively stable indicators of how a learner perceives, interacts with, and responds to the learning environment.

Research shows that students are characterised by significantly different learning styles: they preferentially focus on different types of information, tend to operate on perceived information in different ways, and achieve understanding at different rates. Students whose learning styles are compatible with the teaching style of a course instructor tend to retain information longer, apply it more effectively, and have more positive postcourse attitudes toward the subjects than do their counterparts who 
experience learning/teaching style mismatches (Felder, 1993). In this research Honey and Mumford learning styles instrument was used to group the students according to their learning styles. The result is shown in Table 11.

Table 11 Percentage of third year students according to the learning style

\begin{tabular}{lcc}
\hline Learning Style & Frequency & Percentage (\%) \\
\hline Activist & 26 & 25 \\
Reflector & 41 & 40 \\
Theorist & 20 & 19 \\
Pragmatist & 17 & 16 \\
\hline
\end{tabular}

According to Honey and Mumford, learning styles can be categorized into four main types, namely: Activist (a person who involves actively and aggressively), Reflectivist (a person who likes to observe, think and make his/her own reflection), Theorist (a person who prefers to use principles and theories to derive conclusion) and Pragmatist (a person who posses practical attitude and emphasised facts and truth based on theory, principles or law. Table 11 shows that majority of the students are reflector learning style followed by activist, theorist and pragmatist respectively. The distribution patterns are similar in entrance group analysis (Table 12) where reflector learning style is the main learning style for the students.

Table 12 Percentage of third year students according to the learning style

\begin{tabular}{lccccc}
\hline $\begin{array}{l}\text { Enrolment/ } \\
\text { Entrance }\end{array}$ & Activist & Reflector & Theorist & Pragmatist & Total \\
\hline Foundation & & & & & \\
Program & 2 & 7 & 4 & 6 & 19 \\
Matriculation & 18 & 27 & 13 & 7 & 65 \\
STPM & 6 & 7 & 2 & 4 & 19 \\
Diploma & 0 & 0 & 1 & 0 & 1 \\
Total & 26 & 41 & 20 & 17 & 104 \\
\hline
\end{tabular}

When learning style is analysed according to the students' CGPA grade (Table 13), the result shows that there is no clear sign to indicate that the learning style has specifically contributed to students' high performance achievements.

Table 13 Distribution of learning style according to the third year students' CGPA result

\begin{tabular}{lcccc}
\hline Learning & \multicolumn{4}{c}{ CGPA } \\
style & $\mathbf{2 . 0 0} \mathbf{- 2 . 9 9}$ & $\mathbf{3 . 0 0 - 3 . 4 9}$ & $\mathbf{3 . 5 0 - 4 . 0 0}$ & Total \\
\hline Activist & 0 & 13 & 13 & 26 \\
Reflector & 3 & 21 & 17 & 41 \\
Theorist & 5 & 7 & 8 & 20 \\
Pragmatist & 2 & 9 & 6 & 17 \\
Total & 10 & 50 & 44 & 104 \\
\hline
\end{tabular}

\subsection{Students' Creativity}

Creativity may contribute to higher levels of cognitive complexity thinking style (Zhang \& Sternberg, 2005). However, Table 14 shows that only few students $(11.4 \%)$ are acknowledged as very creative. There is no clear picture regarding the relationship pattern between creativity with the students CGPA achievements (Table $15)$.
Table 14 The percentage of third year students' creative level

\begin{tabular}{cc}
\hline Creativity Level & Percentage \\
\hline Very Creative & 11.4 \\
Creative & 32.9 \\
Not Creative & 47.1 \\
Poorly creative & 8.6 \\
\hline
\end{tabular}

Table 15 Distribution of third year students' creative level according to CGPA

\begin{tabular}{ccccc}
\hline CGPA & $\begin{array}{c}\text { Very } \\
\text { Creative }\end{array}$ & Creative & $\begin{array}{c}\text { Not } \\
\text { Creative }\end{array}$ & $\begin{array}{c}\text { Poorly } \\
\text { Creative }\end{array}$ \\
\hline $3.50-4.00$ & 1 & 12 & 8 & 2 \\
$3.00-3.49$ & 4 & 10 & 22 & 3 \\
$2.50-2.99$ & 2 & 1 & 3 & 1 \\
$2.00-2.49$ & 1 & 0 & 0 & 0 \\
\hline
\end{tabular}

Table 16 Distribution of third year students' creative level according to types of entrances

\begin{tabular}{lcccc}
\hline $\begin{array}{c}\text { Enrolment/ } \\
\text { Entrance }\end{array}$ & $\begin{array}{c}\text { Very } \\
\text { Creative }\end{array}$ & Creative & $\begin{array}{c}\text { Not } \\
\text { Creative }\end{array}$ & $\begin{array}{c}\text { Poorly } \\
\text { Creative }\end{array}$ \\
\hline Foundation & 1 & 6 & 5 & 0 \\
program & 7 & 15 & 23 & 3 \\
Matriculation & 2 & 2 & 4 & 3 \\
STPM & 0 & 0 & 1 & 0 \\
Diploma & & & & \\
\hline
\end{tabular}

Table 16 indicates that it is uncertain that creative students would progress well in their academic performances. This finding was supported by the correlation analysis, where there is no significant correlation between students' CGPA with their level of creativity $(r=-.0173, p=0.151)$.

\subsection{CONCLUSION}

The findings of this study are summarized as follows;

i. Students with different groups' intake showed different correlation indexes between CGPA in the university with their CGPA entrance results.

ii. Majority of the students are highly extrinsic and intrinsic motivated to learn in the university.

iii. The results showed that there is unclear correlation pattern of multiple intelligent with CGPA level of the students.

iv. A student may possess more than one dominant thinking style and it is evident that the high and medium CGPA group students have different thinking styles.

v. Majority of the students are reflector learning style followed by activist, theorist and pragmatist respectively.

vi. Only few students show high creativity traits, however no correlation between creativity with students' CGPA achievement.

In conclusion, understanding of students is important in all areas of teaching and learning. The study revealed that each student brings its own experiences, ability, learning style, thinking style, motivation and creativity into the class and it is for the educator to apply and manipulate his/her experiences to help students to learn effectively. However, the finding of this study is not conclusive as the research has been conducted only at one learning institution. Therefore further study needs to be carried out in order to obtain more useful result for the education community. 


\section{References}

Ainley, M., Hidi, S. \& Berndorff, D. (2002). Interest, learning and the psychological processes that mediate their relationship. Journal of Educational Psychology. 94(3): 545-561.

Aziz bin Nordin dan Hasnah Mohd. Sirat. 1990. Cubaan Murid Menyelesaikan Konsep Mol. Buletin Pendidikan Sains dan Teknik. 2(2): 26-39.

Aziz bin Nordin. 1992. Matematik Sebagi Asas untuk Mengikuti Kursus Kejuruteraan. Prosiding Simposium Kebangsaan Sains dan Matematik Ke $V$. Universiti Teknologi Malaysia. 20-22 Disember,1992.

Aziz bin Nordin. 2003. Peranan Bahasa dalam Pembelajaran Kimia. Buletin Persatuan Pendidikan Sains dan Matematik Johor. 12(1): 59-64.

Curriculum Development Centre. 2006. Curriculum Specifications for Form 5 Chemistry. Putrajaya: Curriculum Development Centre.

Felder, Richard M. and Joni Spurlin, 2005. Applications, Reliability, and Validity of the Index of Learning Styles. International Journal of Engineering Education. 21(1): 103-112.

Felder, R. M. 1993. Reaching the Second Tier: Learning and Teaching Style in College Science Education. Journal of College Science Teaching. 23(5): 286-290.

Gardner, H. 1999. Intelligence Reframed: Multiple Intelligences for the 21st Century. New York: Basic Books.

Gardner, H. 1983. Frames of Mind. New York: Harper and Row.

Honey, P. and Mumford, A. 1992. The Manual of Learning Styles. Second Edition. United Kingdom: Peter Honey.

Honigsfeld, A. \& Dunn, R. 2003. High School Male and Female Learning-Style Similarities and Differences in Diverse Nations. Journal of Educational Reseach. 96(4): 195-206.

Ihejieto, D. O. 1995. Parallelism in Performance and the Multifactor Perspective to the Instructional Process-A Case Study of Poor Achievements in Mathematics in a Single-sex School Setting. Int. J. Math. Educ. Sci. Technol. 26(4): 559-565.
Keefe, J. W. 1979. Learning style: An overview. In J. W. Keffe (Ed.). Student learning styles: Diagnosing and Prescribing Programs. Reston, VA National Association of Secondary School Principals. 1-17.

Kementerian Pelajaran Malaysia. 2006. Pelan Induk Pembangunan Pendidikan 2006-2010. Putrajaya: Kementerian Pelajaran Malaysia.

Lovelace, M. K. 2005. Meta-Analysis of Experimental Research Based on the Dun and Dun Model. The Journal of Educational Research. 98(3): 176183.

Nurulhamizah Azman. 2010. Hubungan Kreativiti Dengan Tahap Pencapaian Kimia Pelajar Tingkatan Empat Di Hulu Selangor. Universiti Teknologi Malaysia, Skudai. Unpublished.

Rafedah Othman. 2009. Perkaitan Antara Kreativiti dan Kemahiran Penyelesaian Masalah Topik Elektrokimia Bagi Pelajar Tingkatan Empat. Universiti Teknologi Malaysia, Skudai. Unpublished.

Slavin, R. E. 2006. Educational Psychology: Theory and Practice. $8^{\text {th }}$ edition. Boston: Allyn \& Bacon

Sternberg, R. J., \& Grigorenko, E. L. 2001. All Testing is Dynamic Testing. Issues in Education. 7(2): 137-170.

Sternberg, R. J., and Wagner, R. K. 1992. Thinking Styles Inventory. New Haven, CT: Yale University. Unpublished.

Tan, O. S., Parson, R. D., Hinson, S.L., and Sardo-Brown, D. 2003. Educational Psychology: A Practitioner-Researcher Approach (An Asian Edition). Singapore: Thomson Learning.

Torrance, E. P. 1974. Torrance Test of Creative Thinking. Lexington: Personel Press Ginn and Company.

Torrance, E. P., McCarthy, B., and Kolesinski, M. T. 1988. Style of Learning and Thinking. Bensenville, IL: Scholastic Testing Service.

Vivian, L. Y. Y. 2007. Gaya pemikiran dan Kesesuaiannya dengan Pencapaian Kimia Pelajar-pelajar Tingkatan Empat di Sekolah-sekolah Menengah Kebangsaan Daerah Pontian. Universiti Teknologi Malaysia, Skudai. Unpublished.

Zhang \& Sternberg. 2005. A Threefold Model of Intelectual Styles. Education Psychology Review. 17(1):1-5. 